age of eighteen should become mandatory "as soon as is practicable". Education for this age-group should not be confined to one particular pattern, however: "the association considers that there is advantage in maintaining both sixth forms in schools and full-time education in colleges of further education alongside experiments in tertiary institutions".

Placing the responsibility for industrial training with the Department of Employment and Productivity, and not with the DES, has, in the opinion of the ATTI, created unnecessary confusion. Some courses of further education, the association claims, are designed to correspond to schemes of training rather than to the needs of the young person, with the result that education and training are becoming separated, and the student does not acquire the theoretical understanding of his training which would allow him to adapt to changes in technique. The ATTI argues that these problems could be alleviated if responsibility for training were vested in a new Department of Education, Science and Training.

As far as the binary system is concerned, the ATTI is very sceptical of proposals to bring all institutions of higher education under a unified administrative structure. Although it accepts the fact that "the present structure has an arbitrary division between the autonomous and the non-autonomous sectors of higher education which is hard to justify", the proposed alternative "would produce a far more arbitrary division between the parts of the further education system offering higher education and the remainder, and would be unworkable as well as unjustifiable". The ATTI argues that the best way to rationalize and standardize course structures would be to reduce the number of local authorities controlling higher and further education, and to set up a National Council for Further and Higher Education, composed of representatives of government, local government, staff, students, industry and commerce. This body should keep the needs of further and higher education under constant review, while similarly constituted regional councils would be responsible for approving plans of local authorities. Once approval is given, however, the ATTI suggests that local authorities should continue to administer their own institutions.

\section{WORLD WILDLIFE FUND}

\section{Anonymous Bounty}

THE British National Appeal of the World Wildlife Fund has suddenly become richer by $£ 250,000$ through an anonymous donation given to assist the appeal's target of $£ 1$ million in European Conservation Year. In making the donation, the donor paid tribute to the part Peter Scott has played in wildlife conservation throughout the world and asked for the donation to be used to establish a Peter Scott Wildlife Endowment Fund, but gave no stipulation as to how the money should be spent. The World Wildlife Fund does not only seek to protect wild animals from film stars with a yen for exotic furs, but also has many other worthy causes and successes to its credit both in Britain and internationally. Between January and May last year, for example, the British National Appeal provided $£ 25,453$ for international projects, which included the sum of $£ 13,747$ towards the cost of enlarging the Coto
Donaña Nature Reserve through the purchase of the Guadiamar Marshes in southern Spain, £1,536 for a road building project for national parks in Botswana, and $£ 7,125$ to help with the establishment of the Hai-Bar Wildlife Reserve in Israel. Nearer home, the appeal is supporting research on the effects of oil pollution on sea birds and on ecological communities, and several nature reserves are benefiting. The fund has not yet found any other generous benefactors to match $\mathrm{Mr} \mathrm{X}$, but it has eleven more months to go before the deadline.

\section{RESEARCH STATIONS}

\section{How to Help Indusiry}

GovernMENT research stations should undertake more industrially sponsored projects, should concentrate on mission-oriented research, and should allow their staff more opportunities to transfer to industry. These proposals, which in effect call for extension of the government's stake in civil research and development, have been put forward by Mr John Lyons, deputy general secretary of the Institution of Professional Civil Servants, a body representing more than 80,000 scientists, engineers and associated specialists in government establishments (The Role of Public $R$ and $D$ in Exploiting Technology, available from the IPCS).

Mr Lyons argues that government research and development provides an important source of new ideas, and of long and medium term research which industry cannot provide for itself. In particular, the government sector can bring a wide range of disciplines and techniques to bear on particular projects, whether it be "back-up" research or research carried out directly under contract to industry. Mr Lyons criticizes the attitude of the Confederation of British Industry, which believes that government research establishments not engaged on defence or community work should be shut down as soon as possible. Such a policy, Mr Lyons argues, would cause a straightforward loss of the effective employment of qualified technological manpower.

To provide a better service to industry, Mr Lyons suggests that the policy management of government research stations should be shared with representatives of industry. This and other measures would remove the basis of the CBI's criticism that government research establishments have no feel for market economics. Mr Lyons says that it would be much more useful if the Confederation of British Industry, "instead of devoting its considerable energies solely to knocking the civil work done by the highly qualified scientists and technologists in the government stations, should bend its efforts together with the institution to securing their freedom to assist industry in the most helpful way".

Government policy, Mr Lyons says, is the chief obstacle to providing a useful service to industry. Arbitrary limits to staff imposed on the research establishments seriously inhibit their ability to do all the work that industry requires, and directors of the establishments should be given more freedom to determine how much work they can take on a repayment basis. Decisions about the nature, amount and timescale of the payments for industrial research should also be left to the directors of research establishments. 